\title{
ICOM \\ Optimism in a sea of uncertainties: the journalistic coverage on the research of new medicines in Brazil
}

\section{Carlos Henrique Fioravanti and César Maschio Fioravanti}

\begin{abstract}
This paper deals with the journalistic coverage of biologically active compounds presented as promising drugs in Brazil. The sample consists of 214 journalistic stories on 40 compounds published in two daily newspapers and a monthly science magazine from January 1990 to December 2016. After 27 years, although journalists and scientists had claimed that all compounds would become drugs in a few years, only two completed the evaluation tests and were approved for commercialisation. The paper provides a series of strategies to build a more analytical view on drug research and development.
\end{abstract}

Keywords

Science and media; Science communication in the developing world

DOI

https://doi.org/10.22323/2.17020202

Context

The practice of science journalism in developing countries like Brazil has been challenging. Rarely journalists have specific training in science and scientific journalism, and scientists hardly value public communication of their scientific work [Shanahan, 2006]. The lack of knowledge about the processes of scientific production as well as of adequate training to communicate scientific findings has caused errors or inconsistencies in news written on the basis of scientific papers and press releases distributed by scientific institutions in Argentina, Chile, Mexico, Ecuador and Brazil [Veneu, Amorim and Massarani, 2008].

The quality of the work carried out by science journalists has been strongly criticised. A group of physicians considered health information presented by the media in Argentina as unreliable [Izcovich et al., 2016]. Ramamurthy [2012] stated that Indian science journalists in general 'failed to understand the complexities involved in the clinical trial process' of new drugs and presented the results with sensationalism. Dentzer [2009] attributed the distortion of the original results to the inability to interpret clinical studies and to the uncertainty about whether the journalist's role was to describe the scenario and views of a fact or just the novelty of the moment. Dentzer argued that journalists sometimes feel the need to exaggerate the relevance of a story to catch the attention of their editors and readers. Often the lack of knowledge and editorial pressure make journalists follow the easy path: to reproduce press releases and just translate what the scientists said, 
without any meaningful analysis [Murcott, 2009]. Journalists cover initial findings more frequently than follow-ups and rarely inform the public when the most recent scientific findings are denied by later experiments [Dumas-Mallet et al., 2017; Resnick, 2017].

Journalistic coverage of new medicines has also shown weaknesses. Moynihan et al. [2000] assessed the coverage of the benefits and risks of two cardiovascular and osteoporosis prevention drugs in 207 news features from newspapers and TV in the United States between 1994 and 1998. They concluded that the news features presented inadequate or incomplete information about the benefits, risks, and costs of these drugs. In a study on the discovery of Viagra and its rapid popularity after its approval in 1998, Tiefer [2006] concluded that news coverage of sexuopharmaceuticals had been 'uncritical and promotional, continuing the saga of superficial health and science journalism'.

The situation in Brazil differs little from that of other countries. Vaz and Portugal [2012] found almost no discussion about the side effects and cost of new drugs presented in 23 stories published in the weekly magazine Veja between 2000 and 2004. The reports exaggerated the benefits of those drugs and presented testimonials to induce readers to consider themselves ill, motivating them to use drugs. Clair [2013] analysed 863 journalistic stories on antidepressant drugs published in the newspaper Folha de São Paulo and Veja between 1970 and 2010. The author concluded that the news uncritically adhered to the presuppositions of pharmaceutical companies, emphasised the novelties and benefits of the new drugs, rarely mentioned their side effects, avoided controversy and presented the results of scientific research as unquestionable truths. This approach is not limited to the coverage about new drugs: the emphasis on novelties, optimism and a triumphalist tone characterised the science stories transmitted from April 2009 to March 2010 in Jornal Nacional, the main Brazilian newscast [Castelfranchi, Massarani and Ramalho, 2014]. Comparative studies recorded the value of scientific production and of national scientists also in Argentina, Mexico and Colombia [Massarani et al., 2008; Ramalho et al., 2016].

In this study we looked at the news on the discovery and development of drugs at a stage still far from production by pharmaceutical companies. The objective was to verify: 1) whether the molecules with biological activity originated or developed in universities, research centres and companies of the country, presented as promising molecules by journalists and scientists, reached the proposed objectives and effectively became drugs, and 2) the way they were presented. The next section deals with the main concepts about drug discovery and development, with the purpose of facilitating the interpretation of the results of this study, which will follow.

Drug discovery and development
The classic research and development (R\&D) model of new drugs involves few actors and places, many scientific demands and uncertainties, and a lot of time and money until a molecule is approved by regulatory agencies and can be marketed. As a general rule, university research centres focus on preliminary pre-clinical findings and trials, and pharmaceutical companies are responsible for clinical evaluations. 
The development of new drugs consists of four main steps, not always followed to the letter or according to their sequence. The first step is the identification and characterisation of a molecule with some biological activity that can help fight a disease. The second step is pre-clinical research, whereby candidate molecules are tested at different dosages in cells (in vitro) and in laboratory animals (in vivo), usually mice, rats and monkeys, in order to assess the toxicity and beneficial effects. A molecule that shows promising results in laboratory animals may not work the same way in humans and, if very toxic, it will be abandoned. The third step is clinical research, whereby safety of use of the molecule with acceptable toxicity is assessed in a small group of patients (phase I). If the results come back as positive, the efficacy, therapeutic potential and the most adequate dosage will be evaluated in a larger group of patients (phase II) and then in an even larger group (phase III). During the last stage of this process, candidates for drugs that present positive results in pre-clinical and clinical studies can be approved by the regulatory authorities of each country (in Brazil, the National Agency of Sanitary Surveillance, Anvisa) and then marketed [DiMasi, Grabowski and Hansen, 2016; FDA, 2016].

Searching for new drugs is a high-risk activity. Only one drug emerges from an average of 1,000,000 molecules evaluated and about 90 percent of them present disappointing results in the pre-clinical phase. The development of a new drug takes an average of 10 years, if done without interruption and with continuous investment, and it can cost from US $\$ 800$ million to US $\$ 1.5$ billion [Mullard, 2016; DiMasi, Grabowski and Hansen, 2016]. Gagnon and Lexchin [2008] cautioned, however, that the pharmaceutical industry spends twice as much on promotion as it does on R\&D in the United States.

Brazilian pharmaceutical companies have no tradition in R\&D of innovative medicines and depend on imported inputs and technologies [Silva, Amato and Novaes, 2016; Dias et al., 2016; Silva, 2017, p. 82-92]. At best, national research centres provide ideas explored by teams of foreign companies. The classic example is captopril. In the 1960s, Sérgio Henrique Ferreira, a Brazilian pharmacologist, together with John Vane, a British pharmacologist, discovered that the venom of a jararaca (Bothrops jararaca) species contained a molecule - a peptide called bradykinin potentiating factor (BPF) - which increased the action of bradykinin on various organs and worked on blood pressure in animal models. He published several papers on BPF23, but failed to turn his discovery into a marketable product: both the support of pharmaceutical companies and patent protection legislation were at the time very deficient in Brazil. Based on these studies, researchers at the US pharmaceutical company Squibb, currently named Bristol-Myers Squibb, completed basic research, developed the drug, and applied for a new drug patent in the 1970s. Ferreira [1994] considered this episode as a classical example of drug development whereby the initial, basic research was carried out at the university, but the end product was achieved by the industry.

The history of the molecule that resulted in captopril — the first in the world's most widely used antihypertensive drug group (the angiotensin converting enzyme inhibitors) - was not sufficient to create a framework that could bring together the necessary stakeholders to develop original drugs, although the changes in this field have been significant over the last decades. A 1971 law eliminated patenting rights for medicines in Brazil and discouraged investment in R\&D by allowing the copying and production of formulations approved in other countries. In 1996, a 
new patent law reinstated the right of patent protection for manufacturers of original medicines. Since its creation in 1999, Anvisa established the guidelines to be followed for the registration of new drugs, based on good results from pre-clinical and clinical tests, such as the FDA [Anvisa, 2013; Anvisa, 2017; Fonseca and Buranello, 2017, p. 19-32]. ${ }^{1}$

In a comparative study, Rezaie et al. [2012] identified 90 innovative drugs and vaccines in pharmaceutical companies in India, 48 in China and 27 in Brazil, most of them at an early stage of development (60 percent of the products were in the pre-clinical or in phase I of the clinical trials). Most clinical trials in Brazil (60 percent) focus on phase III, demonstrating the efficacy of drugs generally developed by multinational companies [Governo do Brasil, 2011]. Investment in innovation remains low. R\&D spending in the Brazilian pharmaceutical industry is much smaller than 15 to 20 percent of the annual net revenue spent by leading global companies or even 6 to 7 percent spent by Indian drug companies [Tigre, Nascimento and Costa, 2016]. There is also low interaction between universities, companies, funding agencies and regulatory authorities, which hampers innovation in the pharmaceutical field. Mazzucato and Penna [2016] argued that the innovation system in Brazil 'displays fragmentation (even antagonism) between the subsystem of education and research and the subsystem of production and innovation, due to the self-orientation of scientific research, and a lack of demand from business for the knowledge produced in academia'.

Because of the high risk, the need for high investment and specialised teams to develop innovative medicines, national pharmaceutical companies have focused on low-tech products, especially generic drugs. Generic drugs represent relatively easy and short ways to get new products, since pre-clinical and clinical studies have already been carried out by the companies that developed the original molecule. The companies interested in producing them, after the expiration of the patent, only have to prove that the new version has the same active principle and efficiency as the original [Valente, 2006; Kermani, 2006; Da Fonseca and Shadlen, 2017]. Created in 1999, the Brazilian generic drug programme represented an opportunity for the growth and technological upgrading of local pharmaceutical companies, whose market share increased from 35 percent in 2003 to 56 percent in 2015 [Pieroni and Pimentel, 2016].

\footnotetext{
${ }^{1}$ Controversy with the synthetic phosphoethanolamine chemical compound (FOS) indicates that the proposed rules are not always followed. For years, a professor of chemistry at the University of São Paulo (USP) produced the FOS in his laboratory and distributed it to interested parties, based on preliminary studies on its effects against cancer. When he retired, the patients claimed to the university the continuity of the capsule supply. The university declined, but a court ruling, originated from the claims of people with cancer, forced USP to produce and distribute the FOS, triggering protests from scientific and medical institutions. In 2015, another injunction banned its production and distribution, as tests on its safety and efficacy had not been carried out. In response to the controversy, the federal government released funding for specialists from public research centres to conduct pre-clinical and clinical FOS testing. Tests completed in 2017 indicated its ineffectiveness against cancer [Ledford, 2015; Teodoro and Caetano, 2016].
} 
We adopted a methodology based on quantitative and qualitative analysis, in order to size the journalistic coverage and then to understand its nature, fulfilling the criteria of reliability and validity of the information collected [Richardson, 2015, p. 70-89]. Instead of examining publications addressed to the general public in which the coverage of science is not frequent, as in previous studies [Vaz and Portugal, 2012; Clair, 2013], we preferred to examine those who presented a section and had their own science team. Newspapers published in the cities of São Paulo, Rio de Janeiro and Recife, in the state of Pernambuco, and Belém, in the state of Pará, have science sections [Amorim and Massarani, 2008; Carvalho, Massarani and Anjos Seixas, 2015], but not all digitised and released their digital collections — essential for a retrospective analysis - for online access. Despite their limited geographic representativeness, we selected two daily newspapers from São Paulo, Folha de São Paulo (hereinafter FSP) and O Estado de São Paulo (ESP), both with science teams and on-line collections. To enrich the sample, we added the Pesquisa Fapesp (PF) monthly magazine, which is specialized in science and technology and also had a complete collection online. ${ }^{2}$

In order to cover a long period of time and to obtain a representative sample of biologically active compounds, we sought the largest possible number of biologically active compounds characterised in local research centres, universities and/or companies in Brazil, announced in FSP, ESP and PF between January 1990 and December 2016. We established that only compounds defined by a name or category (e.g. extract, peptide or protein) and targeted to a specific disease could be included into the sample. We excluded herbal and cosmetic compounds, which have to comply with different requirements from those required for synthetic or semisynthetic purposes in order to be approved by regulatory agencies, and new uses for already marketed medicines.

After defining the inclusion and exclusion criteria, we used the words "promising drug", "innovative medicine", "promising molecule" and "innovative molecule" in FPS, ESP and PF search sites as a starting point to include as many biologically active compounds as possible that had been created by universities, research centres and/or pharmaceutical companies in Brazil, to reconstruct their discovery and development paths and to evaluate how they were presented to the general public. After identifying a compound, we looked for more news about it in the newspaper or the magazine in which it was initially identified and then in the other two selected publications. We adopted the same procedure for each compound found. By doing so, we found the year when the news was first published, when it was presented, and the amount of journalistic stories on each of the compounds. The names of the researchers, research institutions and companies responsible for the molecules served as the basis for searching for other compounds, in order to broaden the sample, according to the inclusion and exclusion criteria, and to minimise any methodological bias.

\footnotetext{
${ }^{2}$ In 2015, FSP, the main newspaper of the state of São Paulo, had a daily circulation of 189,000 printed copies and ESP, the second largest newspaper in São Paulo, 157,000 copies daily; both newspapers target the highest socio-economic classes of the population [ANJ, 2015]. PF is published by Fapesp, a public agency for financing scientific and technological research in the state of São Paulo, and is one of the leading science magazines in this field in Brazil, with a monthly circulation of 23,900 copies, mainly intended for scientists, entrepreneurs, policymakers and general public ['Quem somos', 2016].
} 
Based only on journalistic stories, focused on the year when the compounds were first announced or the following years, we were unable to conclude whether the compounds had progressed or stopped. In order to resolve the problem, we looked for information about the compounds in scientific papers from the PubMed database (https:/ / www.ncbi.nlm.nih.gov/pubmed/) and on the Google Scholar search engine (https://scholar.google.com.br/). This strategy contributed to identify the year of the announcement of the compounds in scientific journals, which was not always the same as in the journalistic publications, and the last stage of development of the compounds examined, thus verifying what happened to them. The personal communication with the researchers responsible for the analysed molecules was another source of information about the stage of research development. The conversations also indicated the difficulties of the work, the strategies adopted to overcome them and usually a few possibilities of interaction with the pharmaceutical companies.

We found 214 stories (204 news features and 10 opinion pieces) about 40 compounds. The compounds were identified by a name and a code $(\mathrm{C} 1, \mathrm{C} 2 \ldots \mathrm{C} 40)$ and organised and sorted according to the year of their announcement in the selected publications, institutions and/or companies responsible for their discovery and development, their origin, disease and/or therapeutic purpose and the last stage of development achieved (Table 1).

When we analysed the stories, we first observed the long and unfinished trajectories of six molecules (C1 to C5 and C7), which had been covered since the $1990 \mathrm{~s}^{3}$ They show the intricated routes of new drug research in Brazil, which branches out into new uses ( $\mathrm{C} 1, \mathrm{C} 2$ and $\mathrm{C} 7)$, and in diverse work strategies, aiming at the continuity of the work, such as the formation of partnerships $(\mathrm{C} 1, \mathrm{C} 2$ and $\mathrm{C} 7)$, the setting up of a research network (C1), of a laboratory (C1 and C2) and of the scientists' own companies (C7).

Table 1: The 40 biologically active compounds found in the two newspapers and in the magazine selected, between January 1990 and December 2016. The compounds are organised chronologically, according to their first record in one of the selected publications ( $2^{\text {nd }}$ column).

\begin{tabular}{|l|l|l|l|l|}
\hline Identification and name (source) & Year & $\begin{array}{l}\text { Institutions/ } \\
\text { companies }\end{array}$ & $\begin{array}{l}\text { Proposed therapeutic targets or } \\
\text { activity }\end{array}$ & $\begin{array}{l}\text { Stories } \\
\left(\mathrm{n}^{\circ} .\right.\end{array}$ \\
\hline $\begin{array}{l}\text { C1. P-Mapa (fungus Aspergillus } \\
\text { oryzae) }\end{array}$ & 1990 & $\begin{array}{l}\text { Farmabrasilis, } \\
\text { Unesp, Unicamp, } \\
\text { USP }\end{array}$ & $\begin{array}{l}\text { HIV/Aids, leishmaniosis, } \\
\text { tubercolosis, cancer. }\end{array}$ & 12 \\
\hline $\begin{array}{l}\text { C2. Lipidic particle (chemical } \\
\text { synthesis) }\end{array}$ & 1994 & USP, iCell & Antitumor carrier, atherosclerosis. & 11 \\
\hline $\begin{array}{l}\text { C3. Pulmonary surfactant (pigs' } \\
\text { lungs) }\end{array}$ & 1997 & $\begin{array}{l}\text { Butantan, USP, } \\
\text { Sadia }\end{array}$ & $\begin{array}{l}\text { Respiratory syndrome in } \\
\text { premature babies. }\end{array}$ & 16 \\
\hline $\begin{array}{l}\text { C4. Vaccine SM14 (recombinant } \\
\text { DNA) }\end{array}$ & 1998 & $\begin{array}{l}\text { Fiocruz, Butantan, } \\
\text { Ourofino }\end{array}$ & Schistosomiasis. & 13 \\
\hline $\begin{array}{l}\text { C5. Human Growth Hormone } \\
\text { (recombinant DNA) }\end{array}$ & 1999 & $\begin{array}{l}\text { Inpe, Hormogen, } \\
\text { Genosys, Biolab }\end{array}$ & Growth deficit. & 12 \\
\hline $\begin{array}{l}\text { C6. Anti-inflammatory (chemical } \\
\text { synthesis) }\end{array}$ & 1999 & USP, Aché & Inflammation & 3 \\
\hline
\end{tabular}

Continued on the next page

\footnotetext{
${ }^{3}$ The course of only one of them, C1, was detailed in a journalistic book [Fioravanti, 2016].
} 
Continued from the previous page.

\begin{tabular}{|c|c|c|c|c|}
\hline Identification and name (source) & Year & $\begin{array}{l}\text { Institutions/ } \\
\text { companies }\end{array}$ & $\begin{array}{l}\text { Proposed therapeutic targets or } \\
\text { activity }\end{array}$ & $\begin{array}{l}\text { Stories } \\
\left(\mathrm{n}^{\mathrm{o}} .\right)\end{array}$ \\
\hline C7. TB vaccine (Mycobacterium) & 1999 & USP, Unicamp & Tuberculosis, cancer. & 27 \\
\hline $\begin{array}{l}\text { C8. Vaccine against } \\
\text { paracoccidioidomycosis (fungus } \\
\text { Paracoccidioides brasiliensis) }\end{array}$ & 2000 & Unifesp & Paracoccidioidomycosis. & 3 \\
\hline C9. Anesthetic (chemical synthesis) & 2000 & USP, Cristália & Pain. & 6 \\
\hline $\begin{array}{l}\text { C10. Spectaline (leaves of Senna } \\
\text { spectabilis) }\end{array}$ & 2000 & unesp & Alzheimer, cancer. & 2 \\
\hline $\begin{array}{l}\text { C11. Extract of Casearia (leaves of } \\
\text { Casearia sylvestris) }\end{array}$ & 2000 & $\begin{array}{l}\text { Unesp, USP, UnB, } \\
\text { Unicamp }\end{array}$ & $\begin{array}{l}\text { Anti-inflammatory, antimicrobial, } \\
\text { cicatrizant. }\end{array}$ & 4 \\
\hline $\begin{array}{l}\text { C12. Extract of Vernonia (leaves of } \\
\text { Vernonia condensata) }\end{array}$ & 2000 & Fiocruz & Analgesic and anti-inflammatory. & 1 \\
\hline $\begin{array}{l}\text { C13. Gomesin (spider } \\
\text { Acanthoscurria gomesiana) }\end{array}$ & 2000 & Usp & Antimicrobial. & 4 \\
\hline $\begin{array}{l}\text { C14. Galactose (guar gum, } \\
\text { Cyamopsis tetragonolobus) }\end{array}$ & 2000 & UFC & Arthritis. & 2 \\
\hline $\begin{array}{l}\text { C15.Myosin-Va (protein } \\
\text { separation) }\end{array}$ & 2000 & USP & Griscelli syndrome, cancer. & 2 \\
\hline C16. Interferon (fetal cells) & 2000 & UFMG & Cancer and viral diseases. & 2 \\
\hline $\begin{array}{l}\text { C17. Evasins (jararaca venom, } \\
\text { Bothrops jararaca) }\end{array}$ & 2001 & $\begin{array}{l}\text { Butantan, UFMG, } \\
\text { Coinfar }\end{array}$ & Antihypertensive. & 11 \\
\hline $\begin{array}{l}\text { C18. Nitrophenols (chemical } \\
\text { synthesis) }\end{array}$ & 2001 & UFJR & Alzheimer. & 3 \\
\hline $\begin{array}{l}\text { C19. Lychnophora extract (leaves of } \\
\text { Lychnophora ericoides) }\end{array}$ & 2001 & USP & Analgesic, anti-inflammatory. & 3 \\
\hline $\begin{array}{l}\text { C20. Physalis extract (Physalis } \\
\text { angulata leaves) }\end{array}$ & 2001 & Unaerp & $\begin{array}{l}\text { Tubercolosis, immunosuppression, } \\
\text { antiprotozoal agents. }\end{array}$ & 4 \\
\hline $\begin{array}{l}\text { C21. LOPAP (Lonomia obliqua } \\
\text { caterpillar venom) }\end{array}$ & 2001 & Butantan & Anticoagulant. & 7 \\
\hline $\begin{array}{l}\text { C22. Mikania extract (leaves of } \\
\text { Mikania spp) }\end{array}$ & 2002 & Unicamp & antitumor, antiulcer, antimicrobial. & 1 \\
\hline $\begin{array}{l}\text { C23. Enpak (rattlesnake venom, } \\
\text { Crotalus terrificus) }\end{array}$ & 2002 & Butantan & Analgesic. & 5 \\
\hline $\begin{array}{l}\text { C24. Jararaca protein (Bothrops } \\
\text { atrox venom) }\end{array}$ & 2002 & IMTM & Anticoagulant. & 1 \\
\hline $\begin{array}{l}\text { C25. Compound based on } \\
\text { palladium (chemical synthesis) }\end{array}$ & 2002 & UMC & Antitumoral. & 3 \\
\hline C26. Hemopressin (rat brain) & 2003 & USP & Antihypertensive. & 4 \\
\hline $\begin{array}{l}\text { C27. Lodenafil carbonate (chemical } \\
\text { synthesis) }\end{array}$ & 2003 & USP and Cristália & Erectile dysfunction. & 18 \\
\hline $\begin{array}{l}\text { C28. Compounds based on } \\
\text { propolis (chemical synthesis) }\end{array}$ & 2003 & Uniban, Unifesp & Antitumoral. & 4 \\
\hline $\begin{array}{l}\text { C29.Iron-based compound } \\
\text { (chemical synthesis) }\end{array}$ & 2004 & PUC-RS & Tuberculosis. & 1 \\
\hline $\begin{array}{l}\text { C30. Papaya enzymes (latex from } \\
\text { Carica candamarcensis) }\end{array}$ & 2004 & UFMG & Cicatrizant, antitumor. & 1 \\
\hline $\begin{array}{l}\text { C31. Amblyomin-X (Amblyomma } \\
\text { cajennense tick saliva) }\end{array}$ & 2005 & Butantan & Anticoagulant, antitumor. & 7 \\
\hline $\begin{array}{l}\text { C32. Oligonucleotide (chemical } \\
\text { synthesis) }\end{array}$ & 2006 & Unicamp, Aché & Diabetes. & 1 \\
\hline $\begin{array}{l}\text { C33. Crotamine (rattlesnake } \\
\text { venom, Crotalus durissus terrificus) }\end{array}$ & 2007 & $\begin{array}{l}\text { Butantan, Unifesp } \\
\text { and USP }\end{array}$ & Antitumor carriers, antitumor. & 4 \\
\hline
\end{tabular}


Continued from the previous page.

\begin{tabular}{|l|l|l|l|l|}
\hline Identification and name (source) & Year & $\begin{array}{l}\text { Institutions/ } \\
\text { companies }\end{array}$ & $\begin{array}{l}\text { Proposed therapeutic targets or } \\
\text { activity }\end{array}$ & $\begin{array}{l}\text { Stories } \\
\left(\mathrm{n}^{\mathrm{o}} .\right)\end{array}$ \\
\hline $\begin{array}{l}\text { C34. Compounds based on nitric } \\
\text { oxide and ruthenium (chemical } \\
\text { synthesis) }\end{array}$ & 2008 & USP & Chagas disease. & 3 \\
\hline $\begin{array}{l}\text { C35. Two steroids (Rhinella jimi } \\
\text { toad venom) }\end{array}$ & 2008 & Butantan & Leishmaniasis and Chagas disease. & 2 \\
\hline $\begin{array}{l}\text { C36. Peptide (Thalassophryne } \\
\text { nattereri fish venom) }\end{array}$ & 2008 & Butantan, Cristália & $\begin{array}{l}\text { Asthma in children and pregnant } \\
\text { women. }\end{array}$ & 2 \\
\hline $\begin{array}{l}\text { C37. Cyanovirin-N (soya-bean } \\
\text { seed) }\end{array}$ & 2009 & Embrapa & Antiviral. & 2 \\
\hline $\begin{array}{l}\text { C38. Chalcone (leaves of Piper } \\
\text { aduncum) }\end{array}$ & 2009 & $\begin{array}{l}\text { UFRJ, Unicamp, } \\
\text { Unifesp, USP }\end{array}$ & Leishmaniasis. & 1 \\
\hline $\begin{array}{l}\text { C39. Lidocaine/prilocaine } \\
\text { (chemical synthesis) }\end{array}$ & 2010 & $\begin{array}{l}\text { Biolab, UFRGS, } \\
\text { USP, UMS, UFRJ, } \\
\text { Unicastelo, USF, } \\
\text { Inmetro }\end{array}$ & Anesthetic. & 4 \\
\hline $\begin{array}{l}\text { C40. Dapaconazole (chemical } \\
\text { synthesis) }\end{array}$ & 2015 & $\begin{array}{l}\text { Biolab, USP, } \\
\text { Unicamp }\end{array}$ & Fungal infection. & 1 \\
\hline
\end{tabular}

Compounds: P-Mapa = protein aggregate magnesium-ammonium phospholinoleate-palmitoleate anhydride; Evasin = endogenous vasopeptidase inhibitor; Lopap = Lonomia obliqua prothrombin activator protease; Enpak = endogenous pain killer. Institutions and companies: Farmabrasilis, a research network; Unesp = São Paulo State University; Unicamp = Campinas State University; USP = University of São Paulo; Butantan = Butantan Institute; Sadia = BRF, Brazilian Food; Fiocruz = Oswald Cruz Foundation; Ourofino = Ourofino Agronegócio; Inpe = Nuclear and Energy Research Institute; Hormogen and Genosys, Inpe' spin-offs; Biolab = Biolab Sanus Farmaceutica; Aché = Aché Laboratory; Unifesp = Federal University of São Paulo; Cristália = Cristália Laboratory; UnB = Brasilia University; UFC = Federal University of Ceará; UFMG = Federal University of Minas Gerais; Coinfar = Consórcio Farmacêutico Nacional (Biolab, União Química, and Biosintética); UFRJ = Federal University of Rio de Janeiro; Unaerp = University of Ribeirão Preto; IMTM = Tropical Medicine Institute of Manaus; UMC = Mogi das Cruzes University; Uniban = Bandeirante University; PUC-RS = Catholic University of Rio Grande do Sul; Embrapa = Brazilian Agricultural Research Corporation; UFRGS = Federal University of Rio Grande do Sul; UMS = Metropolitan University of Santos; Unicastelo = University Camilo Castelo Branco; USF = University of São Francisco; Inmetro = National Institute of Metrology, Quality and Technology.

Most of the compounds (33 out of 40) were released in the 2000s, mainly in the year 2000 (9). It was the pinnacle of genomics. The Human Genome Project, with the participation of 17 countries, was in its final stage (it ended in 2003), presenting the findings on the molecular bases of the human being. Also in Brazil, this area had great visibility due to the genetic sequencing of a disease-causing bacterium in plants and other sequencing projects of microorganisms, plants and animals ['Genome sequencing for all', 2000; 'Fruits of co-operation', 2000]. After examining a sample of 110 news features on genetics and mental illness published in five newspapers and three journals in the United States, Conrad [2001] identified what he called genetic optimism. The discovery of genes associated with schizophrenia, Alzheimer's and bipolar disorder was being announced out loud without any critical analysis of the possibility that they would effectively lead to the cure of these diseases, as it was claimed. Although hopes did not materialise, genetic optimism persisted in subsequent news features [Conrad, 1999; Conrad, 2001]. As 
they wrote about biologically active molecules, journalists may have been infected by genetic optimism and also disregarded the risks and difficulties of developing new drugs. The enthusiasm was temporary: Figure 1 shows a rapid increase in the number of stories until reaching the peak of 30 in the year 2000, and an equally rapid decrease, indicating the lack of follow-up on the research side. As in genetics, the optimism about the continuity of research and drug viability continued, as shown below.

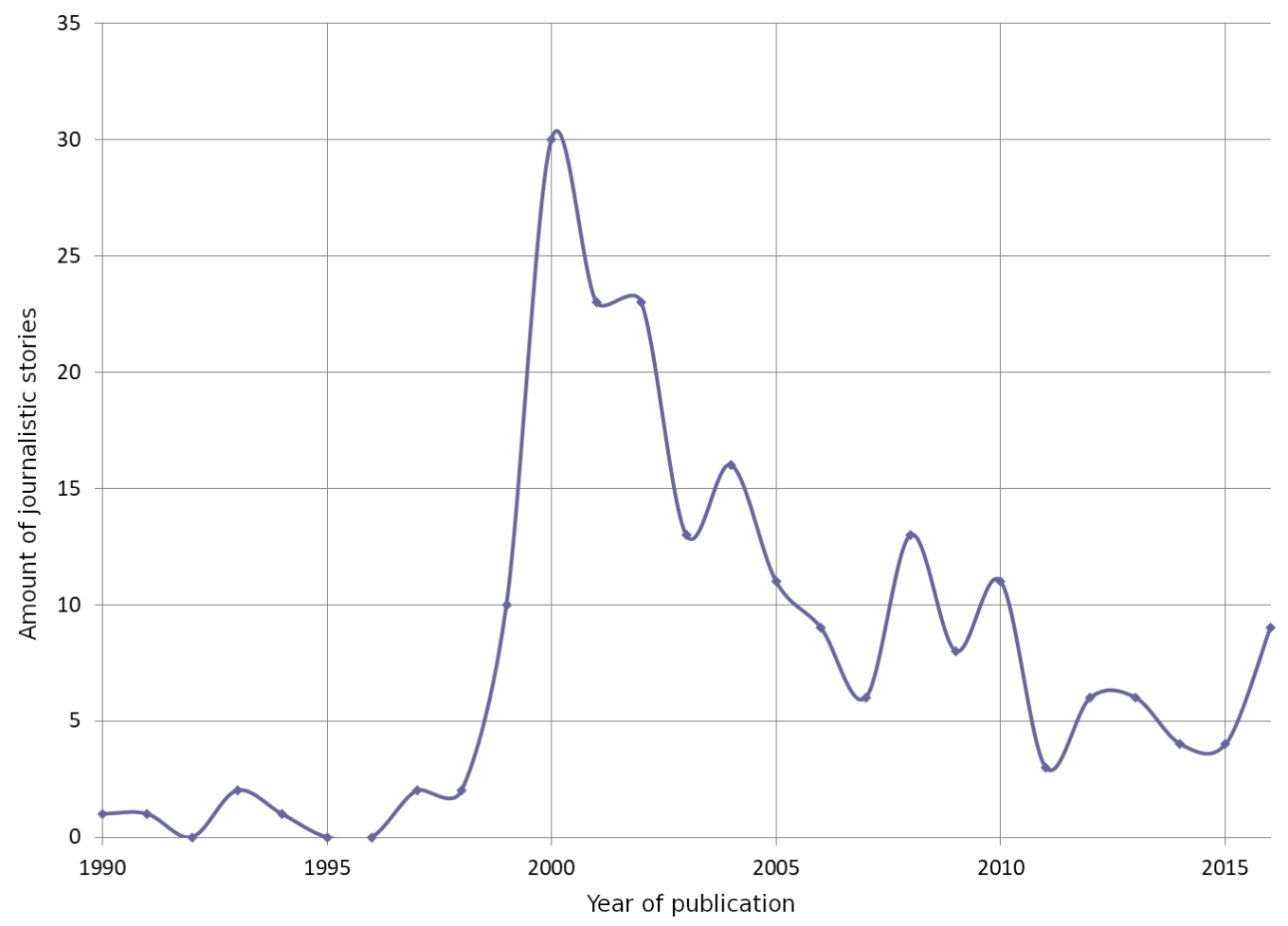

Figure 1. Distribution of coverage in number of journalistic stories (y axis) per year.

The number of stories in each of the publications did not show a significant difference (78 stories in FP, 77 in FSP and 58 in ESP). The number of stories per molecule ranged from $1(\mathrm{C} 12, \mathrm{C} 22, \mathrm{C} 24, \mathrm{C} 29, \mathrm{C} 30, \mathrm{C} 38, \mathrm{C} 40)$ to 27 (C7), with an average of 5.4 stories for each compound. The molecules announced in the 1990s were more intensely reported on and followed than those in the following decades, with the exception of C27, the Brazilian Viagra, reported since 2003, with 18 stories. Despite having different editorial lines and production methods of the stories for the daily or monthly publications, the three publications presented similar coverage. They portrayed essentially the same compounds and presented the same approach, emphasising the alleged therapeutic power of isolated molecules, without considering the barriers they would have to overcome to become drugs.

Most of the compounds (26) were initially identified and evaluated in universities and/or public research institutes (13 in collaboration with companies), resulting from natural sources $(24 ; 11$ derived from animals, 10 from plants, 1 from bacteria and 2 from fungi) and aimed at fighting cancer (11). The majority (26) reached the stage of in vivo tests and four reached the in vitro tests; two $(\mathrm{C} 1, \mathrm{C} 4)$ completed phase I of the clinical trials and two $(\mathrm{C} 2, \mathrm{C} 7)$ phase II; two (C39 and 40, both from companies) were almost completed and awaited regulatory approvals; the research 
with one of them (C6) stopped one year after being announced and one (C3) obtained regulatory approval, but was not produced yet.

Despite the confidence in the success of the molecules presented, only two completed all the tests and obtained government approval to be commercialised: one worked as an anesthetic (C9) and the other against erectile dysfunction (C27), both initiated by the University of São Paulo and developed by Cristália. Although they are to be recognised for showing the cooperation opportunities between public research centres and private companies, they have low innovative content - C9 is an anesthetic resulting from a different portion of components of another anesthetic (bupivacaine) and C27 is a me-too ${ }^{4}$ of Viagra — thus indicating that companies adopt a conservative R\&D strategy for new drugs and prefer molecules of low investment risk. A similar situation was also found in two other compounds (C39 and C40) which had been coordinated by another company. The two molecules that successfully completed all the stages of testing and development account for 5 percent of the 40 identified, below what one might expect, considering that journalists and scientists have ensured that all 40 would become drugs within a few years.

Corpus analysis also revealed three qualitative aspects.

The first aspect is the predominance of the strictly biological/pharmacological approach: the stories essentially dealt with the therapeutic effects of the molecules in animal models or in humans. Only 10 out of 214 stories brought together scientists and institutions in a broader contexts, highlighting the difficulties in obtaining funding, establishing collaborations between research centres and pharmaceutical companies and conducting clinical trials in Brazil, legal obstacles to innovation, delays in clinical evaluation tests of the molecule and other unforeseen circumstances, such as the termination of partnerships.

The second aspect is the unsupported optimism, which disregarded the difficulties regarding funding, team formation and quite selective tests to prove the safety, efficacy and relevance of the molecules. The inconsistency of this optimism can be attested by the deadlines: none of them have been fulfilled. There are countless examples. The lipid particle (C2) would be available in 1995, however it was still in clinical trials in 2016. The pulmonary surfactant (C3) would be released in 2006, but by 2016 it had not begun to be produced yet. The vaccine against schistosomiasis (C4) was to be tested in humans in 1999 and launched in 2015, but it was under clinical evaluation in 2016. The human growth hormone (C5) should start to be produced with a national DNA recombination technology in 2000, year later amended to 2002, but it was still in clinical trials in 2015. The clinical evaluation of the tuberculosis vaccine (C7) would start in 1999, but more recent stories have reported tests on another disease, neck and head cancer. In 2012, a new anesthetic (C39) would start to be marketed in 2013, however in 2015 it still awaited regulatory approval. The fact that the mention of deadlines was concentrated in 1990 and early 2000 seems to suggest that scientists and journalists after that period may have preferred to avoid deadlines that would be difficult to meet.

\footnotetext{
${ }^{4} \mathrm{Me}$-too is a new drug with the same active principle of an already known drug. The me-too of Viagra made in Brazil is a double molecule that in the body decomposes into two units that are identical to the original drug, whose effects had already been characterised, simplifying its development [Gava et al., 2010; Fioravanti, 2008].
} 
The third aspect is the nationalist tone, claiming the alleged superiority of Brazilian science as compared to other countries. According to a story reported in 2005, 'Butantan surfactant [C3] is produced by a world-class methodology, enabling the market price of the dose to be reduced by up to two-thirds'. 'We are very close to having the first parasite vaccine in the world,' said a researcher in a 1999 story, although in 2016 the clinical trials with the schistosomiasis vaccine (C4) were not completed yet. In 2002, a report said that 'through genetic engineering, two small companies would produce the human growth hormone [C5] in Brazil, at that time produced only in Switzerland, Denmark, Italy and the United States.' In 2000, a front-page headline stated that 'Brazilians create a vaccine that prevents and cures tuberculosis' and reported that 'a Brazilian study modifies the creation of vaccines in the world'; in several stories, the tuberculosis (C7) vaccine was presented as 'the first gene vaccine' and 'the first in the world with preventive and therapeutic properties'. Sometimes the stories suggested that the development tests were already completed, as in the title 'Consortium to launch new drugs', referring to collaborative projects $(\mathrm{C} 17, \mathrm{C} 21, \mathrm{C} 23)$ that brought together the Butantan Institute and pharmaceutical companies and had not been completed ten years later. According to a 2003 story, hemopressin (C26) 'could, in the future, displace bradykinin, a molecule discovered in the jararaca venom that is now used in the major antihypertensive drugs', as if only the intrinsic qualities of the new compound would be sufficient to beat the competition with a drug that started to be sold two decades before. In 2016, hemopressin had not reached clinical trials yet.

Conditionals were rare: only five stories revealed uncertainties about the success and achievement of clinical trials. One reported that the pulmonary surfactant (C3) could have other uses, besides preterm newborns, 'if the clinical trial asserted [its] efficiency.' In a story on funding to develop animal-derived compounds (C17, C21, C23, C31), the director of a national pharmaceutical company commented that these molecules were no guarantee of success and he could not ensure they would work in humans, if they were economically viable and whether their company could handle competitors. The researcher responsible for the discovery of a potential molecule against diabetes (C32) gave it five years to reach users, 'if all goes well,' but the partnership with a national pharmaceutical drug company had not progressed.

Discussion

The compounds announced as promising drugs, despite being dealt with assertiveness, represented only the starting point for drug candidates, with no guarantee of continuity. The results of the initial experiments would allow them to be defined only as biologically active molecules. They should not be called medicines, a term which, according to the official definition, represents a 'pharmaceutical product, technically obtained or prepared for prophylactic, curative, palliative or diagnostic purposes', therefore approved by the regulatory bodies. The medicine contains the drug or active principle, the main component of the molecule, responsible for its therapeutic action [Anvisa, 2003; SBFTE, 2013].

The test results obtained in vitro and in vivo, on which the news were based, indicated a potential therapeutic action against a disease or microbe, but the toxicity, safety and efficacy data, which were essential for attesting the viability of a chemical compound, were incomplete. The shortage of information about the molecules and the need for significant investments discouraged entrepreneurs 
interested in new drugs. Researchers who started trading their molecules $(\mathrm{C} 1, \mathrm{C} 2$, $\mathrm{C} 10, \mathrm{C} 13, \mathrm{C} 14, \mathrm{C} 29)$ reported that the directors of pharmaceutical companies lost interest after seeing that they would have to invest more than they would have liked in the development tests. ${ }^{5}$ As a result, partnerships did not evolve, however the problem was not just that companies had no interest in innovative molecules. Stal and Fujino [2016] noticed that universities were reluctant about setting up partnerships with companies, highlighting that 'university-industry relations are not a regular and totally accepted process in Brazilian public universities, which reflect an ideological bias against cooperation with firms.' Without new connections, the compounds remained in the laboratories of public research centres, fueling more academic studies.

Journalists and scientists overestimated the initial phase of the discovery and underestimated the difficulties of the next steps - expanding production, obtaining funding, completing pre-clinical and clinical tests. This perspective explains the optimism in deadlines, assertive language and the predominance of positive results, to the detriment of uncertainty, rejections and analyses, as already observed by Dumas-Mallet et al. [2017] when examining 1,561 journalistic stories on 156 scientific studies. Journalists may prefer positive results and certainty because they assume that their audience looks for tangible information and because they were never trained to handle scientific uncertainty. As a result, uncertainty is ignored and science is presented as being stronger than it really is [Peters and Dunwoody, 2016]. Journalistic stories on promising molecules in Brazil have emphasised the opportunity to celebrate scientific results, as in popular journalism, instead of valuing the attempt, precision, and informativeness of scientific communication [Molek-Kozakowska, 2016]. The results-oriented approach intensifies mistakes and/or inconsistencies in journalistic publications [Veneu, Amorim and Massarani, 2008] and could undermine the credibility of journalists and their media and disappoint readers as the promises announced with enthusiasm do not materialise. There are two emblematic cases that were examined by Nelkin [1995, pp. 3-7, 71-72]: One is interferon, which was advertised with an exaggerated tone and premature enthusiasm, in a promotional coverage, and then referred to the opposite extreme, when the results of the efficacy evaluation tests turned out to be negative; the other one is Prozac, which went from wonder drug to killer drug because its unwanted side effects emerged as the greatest risk of suicide among people who took it. In responding to the interests of academic institutions and companies eager to promote therapeutic novelties, journalists may give in to exaggerated promises, which open the way to disappointment if medicines fail to meet expectations [Nelkin, 1995, p. 45-46].

By announcing promising drugs that would soon be commercialised - however they will hardly be commercialised due to the lack of cooperation between research centres, companies and governing bodies and due to the low investment of companies in R\&D - scientists, journalists and businessmen benefit from the effect of the announcement, a strategy adopted mainly by politicians to present sensational decisions, often without effect or practical continuity, that value mainly personal or institutional interests [Bourdieu, 1997, p. 140]. Public communication about the possibility of a new drug can bring visibility, credibility and money to people, institutions and companies. In 1998, after US physician Judah Folkman announced

\footnotetext{
${ }^{5}$ Personal communication to one of the authors.
} 
that two compounds identified by his team reduced tumor growth, the share value of biotech company EntreMed, which held the rights to the compound, quadrupled [Kolata, 1998; Cooke, 2001, p. 338-40]. Similarly, on the basis of a failed collaborative experience, a Brazilian researcher responsible for one of the examined compounds commented that companies might be more interested in the prestige of a partnership with a public university than in actually investing in the development of new drugs. ${ }^{6}$

Confidence in the success of the announced research, emphasis on hard news and the little attention paid to controversy, scientific uncertainties, and difficulties to be faced in the course of the work dominated the 214 journalistic stories on biologically active compounds published over the course of 27 years, which was fairly similar to the coverage of science news on TV [Castelfranchi, Massarani and Ramalho, 2014; Ramalho et al., 2016]. The optimism about the future of compounds in the initial phase of evaluation was inconsistent and reflects the lack of knowledge about drug development and the peculiarities of scientific production and represents an attempt to draw the attention of readers, as argued by Dentzer [2009], creating expectations that can hardly be met. Most interpretations of the future of the molecules announced were premature, reflecting the hope of moving forward rather than solid connections between research centres, pharmaceutical companies and government, which may effectively result in new drugs. The coverage of the molecules discovered or under development was as uncritical as that of newly launched drugs [Vaz and Portugal, 2012; Clair, 2013].

The news about molecules with biological activity present characteristics of science journalism identified in other studies. Amorim and Massarani [2008] found that science news emphasised discovery and paid hardly any attention to context. Carvalho, Massarani and Anjos Seixas [2015] observed that scientific controversies and uncertainties gained little space in the newspapers of Pará over the course of 130 years of science coverage. This view characterises the classic approach of science journalism, marked by the enthusiasm for the scientist and science, emphasising positive results and certainty about the continuity of the research presented. As an alternative, a wider approach considers science as a collective phenomenon and values the diversity of actors and uncertainties [Fioravanti, 2013].

The results of this study highlight the need for a review of the role of journalists, who could act more as watchdogs than as cheerleaders, as proposed by Rensberger [2009]. In that sense, one of the possibilities to improve the quality of the coverage on new drug candidates is to widen the view to other actors and points of view, in addition to the scientists and their institutions. Drug research and production involves ethical and economic issues, expressed in conflicts of interest between doctors and researchers - who rely on pharmaceutical companies to fund their research - and abuses in clinical trials when multinational companies do not employ in poor or developing countries the same procedures adopted in their home countries [Fugh-Berman, 2013; Palma and Vilaça, 2012].

Essential for the continuity of scientific work, the connections between researchers, laboratories, universities, companies and funding and regulatory agencies should

${ }^{6}$ Personal communication to one of the authors. 
be verified, not just assumed. Journalists could examine obstacles, checking whether there are any funding, any suitable laboratories and research teams, if the active principle was isolated, if its toxicity was assessed, who would produce the compound in sufficient quantity for the evaluation tests, if the institution which hosts the research is ready to partner with companies and who would be producing similar drugs. It is crucial to keep in mind that the advancement of a molecule depends not only on its qualities but also on a network of collaborations and significant investments to enable the necessary tests for its approval, production and commercialisation. The obstacles are so great that in the whole world most biologically active compounds hardly go beyond the laboratories in which they are identified.

Science becomes much richer when viewed as a collective social construction resulting from the negotiations, conflicts, alliances, and interests of diverse groups of actors, including scientists, journalists, businessmen and leaders of academic and governmental institutions [Latour, 1983, p. 141-170; Latour, 2000, p. 70; Fioravanti, 2013]. According to Nelkin [1995, p. vii], science is intrinsically linked to social practices and public policies. By presenting science as a separate culture from other human activities, away from conflicts and social values, and ignoring the process of production and use of scientific knowledge, journalists contribute to the obscuring of science and benefit scientists who seek status and autonomy [Nelkin, 1995, pp. 30,65]. However, a more qualified and impartial performance of journalists may not be enough to improve coverage of science, which also depends on the interests of editors, publications and the science image they intend to convey to their audiences.

A more mature approach to science journalism implies the use of moderation. Scientists may be explicitly optimistic, but journalists should not follow suit, when they wish to exercise impartiality and exemption, two guiding principles of this profession. Journalists should be wary of deadlines for completing the assessment tests provided by scientists, since uncertainty is high in science [Fioravanti, 2013]. Dentzer [2009] recommends that journalists stop publishing black-and-white, extreme-sized news stories and start to consider more nuances to describe complex realities. Nelkin [1995, p. 171] points out that journalists should contribute to the understanding of scientific findings, not only present them in a language that is accessible to the general public, because readers need to understand the social, political and economic implications of scientific work and the limits - as much as the power - of science.

Rensberger [2009] argues that journalists must learn about the processes of scientific production to interpret the findings. Murcott [2009] observes that journalists 'need to have the willingness to acquire more expertise so we can understand the technical details of the science, be able to interrogate and be critical when necessary, and not feel intimidated by those we are interviewing.' Scientists often emphasise the importance of their work based on the publication of the results in specialised journals, but good news for scientists such as publishing an article in a prestigious scientific journal is not always good news for readers of publications targeting wider audiences. The detachment and independent and analytical thinking can still be very useful in guiding science journalism. 
Acknowledgments The authors would like to thank Marko Synésio Alves Monteiro, Ivan da Costa Marques, Raul Cavalcante Maranhão, Valter Rodrigues da Silva and José Roberto Ferreira. They would also like to express their sincere appreciation to their partners at JCOM, who provided excellent suggestions that significantly contributed to enhancing this work.

Translated by Sabina Brusemini

\section{References}

Amorim, L. H. de and Massarani, L. M. (2008). ‘Jornalismo científico: um estudo de caso de três jornais brasileiros'. Revista Brasileira de Ensino de Ciência e Tecnologia 1 (1), pp. 73-84. https://doi.org/10.3895/s1982-873x2008000100005.

ANJ — Associação Nacional de Jornais (2015). Maiores jornais do Brasil. URL: http://www . anj . org. br/maiores-jornais-do-brasil.

Anvisa - Agência Nacional de Vigilância Sanitária (2003). Resolução RDC no 210, de 4 de agosto de 2003. URL: http://www. cff .org. br/userfiles/file/resolucao _sanitaria/210.pdf.

- (2013). Guia para a condução de estudos não clínicos de toxicologia e segurança farmacológica necessários ao desenvolvimento de medicamentos. Anvisa.

- (2017). Manual para submissão de dossiê de Desenvolvimento Clínico de Medicamento (DDCM) e Dossiê Específico de Ensaio Clínico. Anvisa.

Bourdieu, P. (1997). Sobre a televisão. Rio de Janeiro, Brazil: Jorge Zahar.

Carvalho, V. B. de, Massarani, L. M. and Anjos Seixas, N. S. dos (2015). 'A cobertura de ciência em três jornais paraenses: um estudo longitudinal'. Intercom: Revista Brasileira de Ciências da Comunicação 38 (2), pp. 207-230. https://doi.org/10.1590/1809-58442015211.

Castelfranchi, Y., Massarani, L. and Ramalho, M. (2014). 'War, anxiety, optimism and triumph: a study on science in the main Brazilian TV news'. JCOM 13 (3), A01. URL: https://jcom.sissa.it/archive/13/03/JCOM_1303_2014_A01.

Clair, E. S. (2013). 'Antidepressants and Brazilian journalism: a brief history of a cyclothymic relationship (1990-2010)'. Em Questão 19 (1), pp. 275-293.

URL: http://www.brapci.inf.br/index.php/article/view/0000013457/a31d d776bcddc651e6bb404d17c1403c.

Conrad, P. (1999). 'A mirage of genes'. Sociology of Health and Illness 21 (2), pp. 228-241. https://doi.org/10.1111/1467-9566.00151.

- (2001). 'Genetic optimism: Framing genes and mental illness in the news'. Culture, Medicine and Psychiatry 25 (2), pp. 225-247. https://doi.org/10.1023/A:1010690427114.

Cooke, R. (2001). A Guerra contra o câncer - A revolucionária descoberta da angiogênese e as novas perspectivas para a cura do câncer. Rio de Janeiro, Brazil: Objetiva.

Da Fonseca, E. M. and Shadlen, K. C. (2017). 'Promoting and regulating generic medicines: Brazil in comparative perspective'. 41 (5), pp. 1-6.

URL: http://www.scielosp.org/scielo.php?script=sci_arttext\&pid=S1020 $-49892017000100501 \&$ Ing $=$ pt\&nrm=iso.

Dentzer, S. (2009). 'Communicating Medical News — Pitfalls of Health Care Journalism'. New England Journal of Medicine 360 (1), pp. 1-3. https://doi.org/10.1056/nejmp0805753. 
Dias, E. C. F., Ambrosino, M. C. P., Oliveira, N. R. de and Magalhães, J. L. de (2016). 'The dependence on imported pharmaceutical inputs in Brazil: a case study of the nevirapine antiretroviral drug in the Farmanguinhos official pharmaceutical laboratory'. Revista de Gestão em Sistemas de Saúde 5 (2), pp. 125-133. https://doi.org/10.5585/rgss.v5i2.194.

DiMasi, J. A., Grabowski, H. G. and Hansen, R. W. (2016). 'Innovation in the pharmaceutical industry: New estimates of R\&D costs'. Journal of Health Economics 47, pp. 20-33. https: //doi.org/10.1016/j. jhealeco.2016.01.012.

Dumas-Mallet, E., Smith, A., Boraud, T. and Gonon, F. (2017). 'Poor replication validity of biomedical association studies reported by newspapers'. PLOS ONE 12 (2), e0172650. https://doi .org/10.1371/journal . pone. 0172650.

FDA - Food and Drug Administration, U.S.A. (2016). New Drug Development and Review Process. URL: https://www.fda.gov/Drugs/DevelopmentApprovalProce ss/SmallBusinessAssistance/ucm053131.htm.

Ferreira, S. H. (1994). ‘University discoveries and intellectual property rights: From Bothrops jararaca bradykinin potentiating peptides to angiotensin converting enzyme inhibitors'. Brazilian Journal of Medical and Biological Research 27 (8), pp. 1693-1698.

Fioravanti, C. (2008). ‘Cópias Criativas'. Pesquisa Fapesp 152, pp. 38-41.

Fioravanti, C. H. (2013). ‘Um enfoque mais amplo para o Jornalismo Científico. A wider approach to Science Journalism'. Intercom: Revista Brasileira de Ciências da Comunicação 36 (2), pp. 315-332. https://doi.org/10.1590/s1809-58442013000200015.

- (2016). A Molécula Mágica - A luta de cientistas brasileiros por um medicamento contra o câncer. São Paulo, Brazil: Manole.

Fonseca, A. S. and Buranello, S. M. (2017). 'Evolução da legislação de medicamentos no Brasil'. In: Desenvolvimento de medicamentos no Brasil. Ed. by C. R. d. Silva. São Paulo, Brazil: Nelpa.

'Fruits of co-operation' (2000). The Economist. URL: http://www . economist. com/node/6970.

Fugh-Berman, A. (2013). 'How Basic Scientists Help the Pharmaceutical Industry Market Drugs'. PLoS Biology 11 (11), e1001716. https://doi.org/10.1371/journal.pbio.1001716.

Gagnon, M.-A. and Lexchin, J. (2008). 'The Cost of Pushing Pills: A New Estimate of Pharmaceutical Promotion Expenditures in the United States'. PLoS Medicine 5 (1), e1. https://doi.org/10.1371/journal.pmed. 0050001.

Gava, C. M., Bermudez, J. A. Z., Pepe, V. L. E. and Reis, A. L. A. dos (2010). 'Novos medicamentos registrados no Brasil: podem ser considerados como avanço terapêutico?' Ciência E Saúde Coletiva 15 (suppl 3), pp. 3403-3412. https://doi.org/10.1590/s1413-81232010000900015.

'Genome sequencing for all' (2000). Nature 406 (6792), pp. 109-109. https://doi.org/10.1038/35018228.

Governo do Brasil (2011). Anvisa divulga perfil de pesquisa clínica de medicamentos no Brasil. URL: http://www.brasil.gov.br/saude/2011/08/anvisa-divulga-perf il-de-pesquisa-clinica-de-medicamentos-no-brasil.

Izcovich, A., Criniti, J. M., Popoff, F., Malla, C. G. and Catalano, H. N. (2016). 'How much can we trust health related information provided by mass media in Argentina?' Medicina 76, pp. 71-75. PMID: 27135843.

Kermani, F. (2006). 'The future of generics in Brazil'. Journal of Generic Medicines 3 (4), pp. 287-294. https : //doi.org/10.1057/palgrave.jgm. 4940131. 
Kolata, G. (3rd May 1998). 'Hope in the lab: A cautious awe greets drugs that eradicate tumors in mice'. New York Times. URL: http: //www . nytimes . com/1998 /05/03/us/hope-lab-special-report-cautious-awe-greets-drugs-that-er adicate-tumors-mice.html?pagewanted=all.

Latour, B. (1983). 'Give me a laboratory and I will move the world'. In: Science observed. Ed. by K. Knorr and M. Mulkay. London, U.K.: Sage.

- (2000). Ciência em ação: como seguir cientistas e engenheiros sociedade afora. São Paulo, Brazil: Editora Unesp.

Ledford, H. (2015). 'Brazilian courts tussle over unproven cancer treatment'. Nature 527 (7579), pp. 420-421. https : //doi .org/10.1038/527420a.

Massarani, L., Dal Col, F., Buys, B. and Almeida, C. (2008). 'A cobertura de ciência por jornais diários: em pauta a pesquisa nacional na Argentina, no Brasil e no México'. Razón y Palabra 13 (65), p. 5.

URL: http://www.razonypalabra.org.mx/N/n65/actual/lmassarani .html.

Mazzucato, M. and Penna, C. (2016). The Brazilian Innovation System: A Mission-Oriented Policy Proposal. Brasília, DF: Centro de Gestão e Estudos Estratégicos. URL: https://www. cgee.org.br/documents/10195/1774546/The _Brazilian_Innovation_System-CGEE-MazzucatoandPenna-FullReport.pdf.

Molek-Kozakowska, K. (2016). 'Stylistic analysis of headlines in science journalism: A case study of New Scientist'. Public Understanding of Science 26 (8), pp. 894-907. https://doi.org/10.1177/0963662516637321.

Moynihan, R., Bero, L., Ross-Degnan, D., Henry, D., Lee, K., Watkins, J., Mah, C. and Soumerai, S. B. (2000). 'Coverage by the News Media of the Benefits and Risks of Medications'. New England Journal of Medicine 342 (22), pp. 1645-1650. https://doi.org/10.1056/nejm200006013422206.

Mullard, A. (2016). 'Parsing clinical success rates'. Nature Reviews Drug Discovery 15 (7), pp. 447-447. https://doi.org/10.1038/nrd.2016.136.

Murcott, T. (2009). 'Science journalism: Toppling the priesthood'. Nature 459 (7250), pp. 1054-1055. https://doi.org/10.1038/4591054a.

Nelkin, D. (1995). Selling Science - How the Press Covers Science and Technology. New York, U.S.A.: W.H. Freeman and Co.

Palma, A. and Vilaça, M. M. (2012). 'Conflitos de interesse na pesquisa, produção e divulgação de medicamentos'. História, Ciências, Saúde-Manguinhos 19 (3), pp. 919-932. https://doi.org/10.1590/s0104-59702012000300008.

Peters, H. P. and Dunwoody, S. (2016). 'Scientific uncertainty in media content: Introduction to this special issue'. Public Understanding of Science 25 (8), pp. 893-908. https://doi .org/10.1177/0963662516670765.

Pieroni, J. P. and Pimentel, V. P. (2016). 'Brazilian Technological Trajectory in the Pharmaceutical Industry'. BNDES Report. URL: http://www3. weforum.org/docs /Manufacturing_Our_Future_2016/Case_Study_3.pdf.

'Quem somos' (2016). Pesquisa Fapesp. URL: http://revistapesquisa.fapesp.br/en/quem-somos/?.

Ramalho, M., Arboleda, T., Hermelin, D., Reznik, G. and Massarani, L. (2016). 'A cobertura de ciência em telejornais do Brasil e da Colômbia: um estudo comparativo das construções midiáticas'. História, Ciências, Saúde-Manguinhos 24 (1), pp. 223-242. https://doi.org/10.1590/s0104-59702016005000019.

Ramamurthy, N. V. (2012). 'Inept media trials of clinical trials'. Perspectives in Clinical Research 3 (2), p. 47. https: //doi .org/10.4103/2229-3485. 96442.

Rensberger, B. (2009). 'Science journalism: Too close for comfort'. Nature 459 (7250), pp. 1055-1056. https://doi .org/10.1038/4591055a. 
Resnick, B. (3rd March 2017). 'Study: half of the studies you read about in the news are wrong'. Vox Science E Health. URL: http: //www . vox.com/science-and-heal th/2017/3/3/14792174/half-scientific-studies-news-are-wrong.

Rezaie, R., McGahan, A. M., Daar, A. S. and Singer, P. A. (2012). 'Innovative drugs and vaccines in China, India and Brazil'. Nature Biotechnology 30 (10), pp. 923-926. https://doi.org/10.1038/nbt.2380.

Richardson, R. J. (2015). 'Métodos Quantitativos e Qualitativos'. In: Pesquisa Social - Métodos e Técnicas. Ed. by R. J. Richardson. São Paulo, Brazil: Atlas.

SBFTE - Sociedade Brasileira de Farmacologia e Terapêutica Experimental (2013). Newsletter 2/2013. URL: http://www.sbfte.org. br/NL_junho_2013fn.pdf.

Shanahan, M. (2006). 'Fighting a reporting battle'. Nature 443 (7110), pp. 392-393. https://doi.org/10.1038/443392a.

Silva, C. R. da (2017). 'Desenvolvimento de medicamentos inovadores e incrementais: onde estamos?' In: Desenvolvimento de medicamentos no Brasil. Ed. by C. R. d. Silva. São Paulo, Brazil: Nelpa.

Silva, R. E. da, Amato, A. A. and Novaes, M. R. C. G. (2016). 'Pharmaceutical innovation and technological dependence: a study of the Brazilian scenario'. International Journal of Clinical Trials 3 (1), p. 15. https://doi.org/10.18203/2349-3259.ijct20160474.

Stal, E. and Fujino, A. (2016). 'The evolution of universities' relations with the business sector in Brazil: What national publications between 1980 and 2012 reveal'. Revista de Administração 51 (1), pp. 072-086. https://doi.org/10.5700/rausp1224.

Teodoro, C. R. and Caetano, R. (2016). 'O caso da fosfoetanolamina sintética e a preocupante flexibilização das normas sanitárias no Brasil'. Physis 26 (3), pp. 741-746. https://doi.org/10.1590/s0103-73312016000300002.

Tiefer, L. (2006). ‘The Viagra Phenomenon'. Sexualities 9 (3), pp. 273-294. https://doi.org/10.1177/1363460706065049.

Tigre, P. B., Nascimento, C. V. M. F. do and Costa, L. S. (2016). 'Windows of opportunities and technological innovation in the Brazilian pharmaceutical industry'. Cadernos de Saúde Pública 32 (suppl 2). https://doi.org/10.1590/0102-311x00103315.

Valente, V. (2006). 'Generics in Latin America: An analysis of the Brazilian experience'. Journal of Generic Medicines 4 (1), pp. 30-36. https://doi.org/10.1057/palgrave.jgm. 4950045.

Vaz, P. and Portugal, D. B. (2012). 'The new gospel: medicine marketing and science journalism in the Brazilian news magazine Veja'. Comunicação, mídia e consume 9 (2), pp. 37-60. URL: http://revistacmc.espm.br/index.php/revistacmc/arti cle/viewFile/342/pdf_2.

Veneu, F., Amorim, L. H. and Massarani, L. (2008). 'Science journalism in Latin America: how the scientific information from a scientific source is accommodated into a journalistic story'. JCOM 7 (1), A03. URL: https://jcom.sissa.it/archive/07/01/Jcom0701\%282008\%29A03. 
Carlos Henrique Fioravanti has been a science journalist and has been writing about science, environment and technology since 1985 for Brazilian journals, such as Pesquisa Fapesp, and internacional ones, such as The Lancet. In 2007, he became a Fellow of the Reuters Institute for the Study of Journalism at Oxford University, U.K., and he completed his PhD at the State University of Campinas (Unicamp) in 2010. Author of "The Magic Molecule - The struggle of Brazilian scientists for a drug against cancer" (2016). E-mail: chfioravanti@gmail.com.

César Maschio Fioravanti is a biomolecular physicist specialised in drug discovery and development. In 2012, he graduated in biomolecular physics and, in 2015, he completed his Master's degree in molecular modeling at the Institute of Physics of São Carlos at the University of São Paulo. E-mail: cesarmaschio@gmail.com.

How to cite

Fioravanti, C. H. and Fioravanti, C. M. (2018). 'Optimism in a sea of uncertainties: the journalistic coverage on the research of new medicines in Brazil'. JCOM 17 (02), A02_en. https:/ /doi.org/10.22323/2.17020202. 